\title{
FEMALE RELIGIOUS AUTHORITY, RELIGIOUS MINORITY AND THE AHMADIYYA: The Activism of Sinta Nuriyah Wahid'
}

\author{
Asfa Widiyanto \\ IAIN Salatiga - Indonesia | widiyanto_asfa@daad-alumni.de
}

\begin{abstract}
In the present-day Indonesia, cases of discrimination and violence towards minorities are still prevailing. A number of Indonesian personages who play a strong role in defending minorities have been observed, most particularly Muslim minority groups such as the Shi'ism and the Ahmadiyya. One of these personages: Sinta Nuriyah Wahid (b. 1948). One may say that Sinta is a female Muslim scholar-activist who is rooted in traditionnalist Islam, and accordingly is considered a figure of authority in speaking in the name of Islam. This article is dealing with the role and authority of this female scholaractivist in promoting the rights of the Ahmadiyya in contemporary Indonesia. The first concern of this paper is dealing with Sinta's roles in protecting the Ahmadiyya in Indonesia. The second concern is dealing with the ways in which Sinta and her ideas on protecting the Ahmadiyya wield authority on present-day Indonesian Muslims.
\end{abstract}

Keywords: Female religious authority, the Ahmadiyya, religious minority, minority protection.

\section{Introduction}

The Ahmadiyya is a religious movement established by the Indian personage Mirza Ghulam Ahmad (1835-1908). Wilfred C. Smith subsumes the Ahmadiyya under the category of theological movement,

\footnotetext{
${ }^{1}$ This article has been developed from parts of my research report in the framework of "AvH-Return Fellowship", which was funded by the Alexander von HumboldtFoundation, carried out from December 2013 until December 2014, under the supervision of Prof. Patrick Franke und Prof. Claudia Derichs.
} 
whilst H.R. Gibb considers the Ahmadiyya as intellectual movement. ${ }^{2}$ The adherents of the Ahmadiyya regard themselves as parts of Muslim community and even maintain that their practices are in accordance with the pristine tenets of Islam. Nevertheless the standpoints of the Ahmadiyya have been contested by mainstream Sunni-Muslims, most particularly due to Ahmadiyya's alleged rejection of Muhammad as the last prophet. ${ }^{3}$ Other contentious notions of Ahmadiyya include the notion of revelation, the death of the Prophet Isa, and the Messias. ${ }^{4}$

Marking of the boundaries between orthodoxy and heterodoxy, as shown in history, is most particularly in the hands of those in power. Mainstream religious group-Sunnite in the case of Islam-is accordingly possess more authority in delineating such boundaries. Arabcentered Islam is considered more orthodox than any other expressions of Islam outside Arabian Peninsula. In this line of thought, we begin to realize that the Ahmadiyya is probably seen as "Indian expression of Islamic religiosity", and accordingly less orthodox than those develop in Arabian Peninsula. Moreover, the Ahmadiyya movement is alleged to proclaim its own prophet which is not Arab.

In Indonesia, The Ahmadiyya constitutes a religious minority, and accordingly it has to deal with the boundaries of religious freedom which it could exercise in Sunni-majority Indonesia. ${ }^{5}$ Its presence in Indonesian archipelago has been felt since 1920s. The Lahore branch of the Ahmadiyya in the country established the "Indonesian Ahmadiyya Movement" (Gerakan Ahmadiyya Indonesia, GAI), whilst the Qadiani branch organized themselves into the "Indonesian Ahmadiyya Congregation" (Jamaah Ahmadiyya Indonesia, JAI). These two factions have successfully attracted more than 300,000 followers across the country.

The Ahmadis played their role in struggling for the independence of Indonesia (in 1945). Many Ahmadi figures, such as R. Muhyiddin and Sayyid Syah Muhammad were involved in physical struggle against Dutch colonialists. Other Ahmadis such as Abdul Wahid and Ahmad

2 Azyumardi Azra, "Pengantar," Iskandar Zulkarnain (ed.), Gerakan Abmadiyah di Indonesia (Yogyakarta: LKiS, 2005), p. ix.

3 Shi Xueqin, "Implications of Islam and Pluralism in Post-Suharto Indonesia," Suvannabbumi, 6 (2014), p. 25.

${ }^{4}$ Iskandar Zulkarnain, Gerakan Abmadiyah di Indonesia (Yogyakarta: LKiS, 2005), p. 261.

${ }^{5}$ Melissa Crouch, Indonesia, Militant Islam and Abmadiyab: Origins and Implications, SSRN Scholarly Paper (New York: Social Science Research Network, 2010), pp. 4-5. 
Nuruddin also contributed to the independence of Indonesia, by serving as broadcasters which announced the independence of Indonesia to the world. ${ }^{6}$

However, the Rabitah al-Alam al-Islami (Muslim World League) in 1974 declared that the Ahmadiyya is not part of Muslim community, and this followed by the Majelis Ulama Indonesia (the Council of Indonesian Muslim Scholars) which labelled the Ahmadiyya as deviant sect. ${ }^{7}$ All this led to the discrimination and even persecution to the Ahmadis in Indonesia.

\section{Sinta Nuriyah Wahid and the Justification of Her Authority}

In the 1980s, Sinta began her career as part-time journalist in Indonesian magazines (Zaman Magazine and subsequently Matra Magazine). Her career as a journalist came to an end when she got into an accident in $1993 .{ }^{8}$ Sinta's standing as a figure who promotes peace and harmony has led her to obtain "Soka Women's College Commendation of Friendship" award in 2012 from Soka Women's College at the University of Soka, Japan. The appreciations to this awarding can be read for instance in@yennywahid, @fahiraidris, and @agoessis (July 10, 2012).

Sinta revealed that she never even thought briefly that she would devote her time as a woman activist. She exposed this in the following words, "This is because, during my life I have never encounter any gender discrimination. My parents did not differentiate between boys and girls. After marriage, I got a husband who respected a wife".?

Sinta's authority rests in her erudition of Islamic knowledge, which she gains mostly during her study at the Pesantren. Sinta once studied at the Pesantren Krapyak, Yogyakarta, mostly under the supervision of Maksum Ali and Attabik Ali. Her writings and talks obviously indicate that she posit herself as Muslim scholar and women's activist. Sinta is noticeable from the greater part of his audience by the fact that she is

\footnotetext{
${ }^{6}$ Ilyas Marwal, "Kata Pengantar Ahli," Ihsan Ilahi Dzahir, Abmadiah Qadianiyab: Sebuah Kajian Analitis, translated by Harapandi Dahri Jakarta: Balai Penelitian dan Pengembangan Agama, 2008), p. xi.

7 Ibid., xii.

8 Tina Savitri, "Sinta Nuriyah Wahid dan Jurus Menembus Pesantren," Pesona (2011), p. 64.

${ }^{9}$ Ibid.
} 
thoroughly adept in Arabic. This proficiency facilitates her in understanding the major texts of Islam, including the Koran, Hadith, Islamic law and Islamic mysticism. The proficiency in standard Arabic and subsequent mastering of classical Islamic texts thus constitute important credentials of Sinta's authority. Her mastering of Arabic and classical Islamic scholarship have been eloquently demonstrated in her critical study of the book entitled 'Uqüd al-lijayn.

Besides, Sinta's charisma derived mainly from her father, Muh Syakur and her husband, Abdurrahman Wahid. Nobody will deny that her position as the wife of Abdurrahman Wahid plays a significant role in her standing as authority on Islam in Indonesia. The existence of the factors does not necessarily mean negating the inner quality of Sinta. Sinta's authority lies mainly in her erudition of Islamic sciences which she learned from traditionally acknowledged institutions, the Pesantren. Her further education, most particularly her Master's degree at the University of Indonesia, Jakarta, enhances her qualification as Muslim scholar who is able to respond to the challenges of modern society. Such combination is considered strategic in winning the reception among traditionalist and modernist Muslims in the country.

Another source of Sinta's charisma is her spiritual training (riyada rühaniyya). As a pious Muslim and a person who has been nurtured within the milieu of religious scholars, she has been acclimatized to undergo such training. Sinta's daughter ${ }^{10}$ reveals an observation that her mother practices the fasting of Dawud, in the sense of fasting one day and not the next. Accordingly, when Sinta's daughter plans to invite her mother for lunch, she has to make sure that her mother is not fasting at that day. She acknowledged that her mother's supplication plays a significant role for her success.

Sinta also has different view of a well-known statement circulated in the santri community reads as follows "li-yakun walad al-asad asadan la hirratan" (the son of lion should become a lion, not a cat that indicates that the leader's charisma can be effectively and fully transferred ${ }^{11}$ to his son. Accordingly many kiais are anxious if they do

"Yenny Wahid dan Puasa Daud Sinta Nuriyah", (December 23, 2014), http://www.tempo.co/read/news/2014/12/23/219630423/Yenny-Wahid-dan-Puasa-Daud-Sinta-Nuriyah, accessed February 9, 2015

11 The transfer of charisma is designated, in the vocabulary of Max Weber, as "routinisation". See, Reinhard Bendix, "Reflections on Charismatic Leadership," Asian Survey, 7 (1967): pp. 341-352. 
not have sons whom they could transfer their charisma and whom they trust in continuing their leadership. A son is deemed to be the best sort of successor for his father. Due to this adagio and belief, Sinta has been questioned by many people, why she does not have a son, who would continue to the activism of her husband, Abdurrahman Wahid. In response to this, Sinta argues that her daughters could also continue such a struggle, and we should not disregard women. ${ }^{12}$

Sinta's credentials of authority allow her to speak in the name of Islam. Her grounding in traditionalist Muslim scholarship also allow her to criticize some features of Islamic scholarship, most particular hadith and the opinions of Muslim scholars which disregard the position of women, without losing her authority. What is interesting for me that Sinta shows her agreement with gender equality, a sensitive theme for traditionalist Muslim scholars in Indonesia, most notably in the circle of the Nahdlatul Ulama. Nevertheless we hardly find any traditionalist Muslim scholars who oppose her in public.

Sinta's standing is distinct to such feminist Muslim as Siti Musdah Mulia (research professor at the Indonesian Institute of Science, (b. 1958)), which is often delegitimized by the conservative Muslims by stigmatizing her as liberal feminist. Siti Musdah Mulia is known as the scholar-activist who energetically promotes the idea of "reformist Muslim woman". For Mulia, the "reformist Muslim woman"13 refers to the Muslim woman who is concerned with the promotion of democracy, pluralism, justice and equality. Although Mulia was part of the board of the Majelis Ulama Indonesia, ${ }^{14}$ she has been stigmatized as a liberal feminist by the conservative Muslims, most notably due to her viewpoints which seem to defend homosexuality and her involvement in proposing a counter legal draft to "Compilation of Islamic Law".

If using Effendy's ${ }^{15}$ dichotomy (legalist-formalist versus substantialist), it seems that Sinta would fit better in the framework of

\footnotetext{
12 “Tupperware Shecan”, ANTV, December 20, 2014.

13 For detailed elaboration of "reformist Muslim woman" please see Siti Musdah Mulia, Muslimah Reformis: Perempuan Pembaru Keagamaan (Bandung: Mizan, 2004).

${ }^{14}$ Siti Musdah Mulia's activism as board of the Majelis Ulama Indonesia is recorded for instance by Ahmad Baso "Pengantar Editor," Siti Musdah Mulia, Muslimah Reformis: Perempuan Pembaru Keagamaan (Bandung: Mizan, 2004,) p. xxv.

${ }^{15}$ Bakhtiar Effendy, "Islam: Eksistensi Agama dalam Politik Indonesia," S.P. Lili Tjahjadi, Agama dan Demokratisasi: Kasus Indonesia (Yogyakarta: Kanisius, 2011), pp. 77-97.
} 
substantialist rather than legalist-formalist. Effendy highlights two different strategies within Indonesian Muslim communities pertaining to the relation between Islam and democratic politics, namely legalistformalist versus substantialist. The legalist-formalist is concerned with symbols, forms, and particularistic messages of Islam; whilst the substantialist pays more attention to the content, meaning, and universal messages of Islam. The legalist-formalist struggles for symbolic-ideological nuances of Islamic politics. The substantialist strives to develop substantial and meaningful nuances of Islamic politics.

It is apparent that Sinta's viewpoint is in line with that of her husband, Abdurrahman Wahid. Abdurrahman belongs to the scholars who place Islam in the framework of the universality of civilization. This universalism of Islam is embodied in its teachings which show its appreciation towards humanity and civilization. Such cosmopolitanism has been understood and practised most particularly by Muslims during their majesty, in the sense that they are receptive to the scientific achievements of other civilizations. ${ }^{16}$ Such a standpoint stands in contrast with that of conservative Muslims, who perceive that Islamic civilization has been genuinely and exclusively developed within the framework of best milieu and practices of Muslim people.

These conservatives show their disagreement to the idea that some parts of Islamic thought and civilization have been adapted from other civilizations. They defend a sort of idealized manbaj al-fiker al-islami (Islamic mode of thinking) and consider this a part of their identity, which is distinct to that of other modes of thinking. They even regard those mingle Islamic teachings with other modes of thinking as sticking into manbaj al-fiker alla-islami (un-Islamic mode of thinking). They hesitate to label themselves as biz̧ (party) or haraka (movement) but would rather prefer to signify themselves as manhaj (way of life).

Sinta's viewpoints have something in common with Husein Muhammad, a reputed Muslim scholar (kial) from Cirebon, West Java. Husein Muhammad is recorded as one of the founding fathers of Fahmina Institute, a Cirebon-based Non-Governmental Organization which strongly advocated gender equality in Muslim society. His mastering of Islamic scholarship allows him to be the leader of the Pesantren Dar al-Tauhid, Argowinangun, Cirebon. Due to his concern

16 Umaruddin Masdar, Membaca Pikiran Gus Dur dan Amin Rais tentang Demokrasi (Yogyakarta: Pustaka Pelajar, 1999), p. 167. 
with gender equality he is often attributed as "kiai gender" (Muslim scholar on gender, or Muslim scholar who is aware of gender equality). ${ }^{17}$

Hussein Muhammad, in this sense, can be regarded as Sinta's fellow, a person who shares some viewpoint with her, support her ideas, and becomes part of her networks. It is worth remarking that Hussein Muhammad contributed on Sinta's project of criticizing classical Islamic scholarship on women. Husein Muhammad also joined Sinta's NGO, Puan Amal Hayati. The networks with a fellow such as Husein Muhammad allow her to strengthen her authority and influence in Muslim society. Sinta's current position as the chairman of the Special Rapporteur on Freedom of Religion of the National Commission for Women gives her more possibility to build her networks and to maximize her outreach in promoting minority rights and freedom of religion, most particularly among women.

The Puan Amal Hayati (and its networks with the some Pesantrens in the framework of women's empowerment) in some ways can be considered as Sinta's jamā'ah (inner circle). This jama' $a b$ constitutes the community which listen and support Sinta's ideas and activism. The broader audience which attend the events held by Sinta (like her Ramadan programmes with the minorities) can be regarded as Sinta's mustami un (listeners, audience), if we employ the terminology of classical Islamic scholarship. This community cannot be associated with "religious gathering" (pengajian) as it is not attended exclusively by Muslims but also by people from different religious and cultural backgrounds. In this forum, the people learn about spirit of life, tolerance and co-existence.

Through Puan Amal Hayati, Sinta strives to perform a kind of "cultural broker" between the Pesantren as sub-culture with the modernity, most particularly with such notions of women's empowerment and gender equality. Sinta seems to make use her authority within the Pesantren to maximize her activism in women's empowerment and gender equality. During my interview with Sinta ${ }^{18}$, she frequently stated that if she succeed in promoting women's empowerment in the circle of Pesantren, it would be easier for her to promote such a notion within a wider Muslim community.

\footnotetext{
${ }^{17}$ Based on interview with Husein Muhammad, March 25, 2015.

${ }^{18}$ Interview with Sinta Nuriyah Wahid, Jakarta, September 7, 2011.
} 
A significant degree of appreciation towards Sinta can be observed in Youtube. This for instance can be seen from the Youtube video entitled, "The welcoming speech of Sinta Nuriyah Wahid at the occasion of $1000^{\text {th }}$ day commemoration of Abdurrahman Wahid", which was viewed 2,053 times, as of December 15, 2014.19

\section{Sinta Nuriyah Wahid and the Activism of Her Late Husband, Abdurrahman Wahid}

Sinta's ideas on pluralism and minority rights are considered by many to be in conformity with those of her husband, Abdurrahman Wahid. Many people detect the apparent influence of Abdurrahman Wahid's ideas on Sinta. This can be observed, for instance, that in some opportunities, Sinta explains the pluralism of Abdurrahman Wahid. Sinta's vicinity with the ideas of Abdurrahman Wahid is eligible, since, as a wife, Sinta has many opportunities to discuss with her husband, and in the ends this let her to accept some of her husband's ideas. One Twitter account points out that he was glad to hear Sinta's talks which elaborates in detail the position of Abdurrahman Wahid pertaining to religious pluralism (@lukmansaifuddin, January 22, 2014).

It seems that Sinta strives to continue and develop her husband's legacy pertaining to the promotion of democracy and human rights, most particularly by acting as a patron for the activists of democracy and human rights. Serving as a patron for the promotion of democracy and human rights is deemed crucial in present-day Indonesia, without which the promotion of these values could not obtain many supports from the people.

Sinta reveals three modalities of providing protection to the advocates of democracy and human rights. First, legal protection, it is by providing legal advocacy to them. Second, physical protection, it is by rendering them a shelter to avoid from intimidation. Sinta explained that this second type of assurance was performed by her husband, who provided a shelter to the activist who was threatened physically, by letting them to stay in the house of some kiais, with security assistance from some elements within the Nahdlatul Ulama.

19 "Sambutan Istri Alm Gus Dur (Sinta Nuriyah Wahid) pada acara peringatan 1000 hari Gus Dur," https://www.youtube.com/watch?v=dcNZnVA_5KE, accessed June $5,2014$. 
Third, cultural and theological protection, it is by developing a logic which could serve as the basis and legitimacy of the advocates of democracy and human rights so that their struggle could be acknowledged by the society. Sinta explains that this third ilk of assurance was also performed by her husband, Abdurrahman. At the time when many activists of democracy and human rights were labelled as liberals, Abdurrahman included them as parts of the family of the Nadlatul Ulama. This inclusion made these activists comfortable and, at the same time, made the anti-democracy and anti-human rights groups hesitant to intimidate further these activists. ${ }^{20}$

It is most particularly in the third type of assurance that Sinta and her husband have done their best to perform their roles as religious authorities. Providing theological arguments pertaining to democracy and human rights by a religious authority is necessary so that these values could develop smoothly in Muslim populated country such as Indonesia. It is worth remarking that many conservative religious people in Indonesia are convinced that human rights and democracy are alien to their religion. The same tendency also encountered, in another Muslim country, namely Malaysia. The current Malaysian prime minister Datuk Seri Najib Tun Razak is reported ${ }^{21}$ to have said that "human rightism", humanism, liberalism and secularism are new religions that threat Islam.

Sinta regards her husband to be the source of inspiration for anyone who cares and respect human dignity. Further, she felt the necessity of continuing her husband's struggle. She says, "There is no higher tribute to Abdurrahman Wahid other than continuing his struggle, by uphold justice, caring for democracy and pluralism, as well as keeping the values of humanity as a manifestation of 'Islam as blessing for the world"' 22 (rabma li al-älamin).

20 "Sinta Nuriyah Wahid: tidak ada Pola Umum Kekerasan pada Perempuan," http:/ /www.satuharapan.com/read-detail/read/sinta-nuriyah-wahid-tidak-ada-pola-umum-kekerasan-pada-perempuan, accessed May 15, 2014.

${ }^{21}$ See: "PM Says Human Rightism, Humanism, Secularism New Religion Threatening Islam," http://www.themalaymailonline.com/malaysia/article/pm-says-human-rightism-humanism-secularism-new-religion-threatening-islam, accessed on May 16, 2014.

22 "Sinta Nuriyah Hadiri Semalam bersama Gus Dur," http://www.wahidinstitute.org/v1/News/Detail/?id=438/hl=id/Sinta_Nuriyah_Hadiri_Semalam_Bersa ma_Gus_Dur, accessed April 5, 2014. 
The phrase "rahma li al-'alamin" originates from one Qur'anic verse: "Wa-mā-arsalnāka illā rahmatan lil-'ălamin" (And We have sent you (O Muhammad) not but as a mercy for all creation) (Al-Anbiya': 107)). This phrase has been used many Muslim scholars from various parts of the world to accentuate tolerant Islamic teachings, and to underline that Islam should not be exploited for committing any violence.

Sinta admits that her position as the wife of Abdurrahman Wahid has helped her in performing her activism in the circle of Pesantren. It is widely known that Abdurrahman Wahid was a respected figure within the Nahdlatul Ulama. Due to Sinta's special position, Khofifah Indar Parawansa (the former minister of Women empowerment, 19992001) stated that, "If it were not Sinta who perform [this activism], there would be many kiais who oppose this"23.

\section{Sinta Nuriyah Wahid and the Justification of Minority Rights}

Sinta stresses that the independence of Indonesia in 1945 was struggled by all components of society. Hence, both the government and the society should work together to consider the people around them as fellow citizens and are responsible for maintaining harmony. Furthermore, Sinta invites people to live in harmony, hand in hand, and respect each other most notably to the minority communities. According to Sinta, living in harmony and respecting minority are good values and do not contradict to the teachings of Islam. Sinta refers to the examples laid down by the Prophet Mohammed. The Prophet Mohammed taught harmony as outlined in the Charter of Medina that the Muslims can live in harmony, coexistent with other faith communities as well as protect minorities. ${ }^{24}$

In this regards, it may be detected how Sinta provides theological arguments pertaining to the necessity of respecting minorities. Her standing in interpreting Islamic texts is distinguishable from many other woman activists who do not master Islamic texts. This capacity makes her an authority in actualizing the Islamic texts to the current

\footnotetext{
23 Savitri, "Sinta Nuriyah, p. 66.

24 "Sinta Wahid: Kalau Bilang Toleransi Lebih Baik Mbok Lihat Kondisi Sebenarnya," (August 16, 2013), http://nasional.kompas.com/read/2013/08/16/1811371/Sinta.Wahid.Kalau.Bilang.Toleransi.Lebih.Baik.Mbok.Yo.Lihat.Kondisi.Sebenarnya, accessed December 19, 2013.
} 
condition, most notably in the case of the necessity of respecting minority groups.

Sinta's elucidation of the Charter of Medina is in line to that of A. Muqtedar Khan:

On the basis of the Compact of Medina, Muhammad ruled Medina by the consent of his citizens and in consultation with them. The compact of Medina did not impose Shari'ah on anyone, and no laws were understood as given prior to the compact. Prophet Muhammad's divine mission or the divine message of the Qur'an did not in any way undermine the principles of the compact, though of course the principles enshrined in it echo Islamic principles of equality, consultation and consent in governance. As long as Islamic jurists focus on the post-Muhammad development in the discipline of Islamic legal thought, and privilege it over Muhammad's own practice, authoritarianism will trump democracy in the Muslim milieu. ${ }^{25}$

When skimming through contemporary Islamic scholarship, it is realized that there have been some scholars who devote their time in devising Islamic conception in respecting and appreciating "the other". The Egyptian scholar Ahmad Juhayni and Muhammad Mustafa, for instance, are known for their book entitled Al-Islam wa al-Akhar (Islam and the other). Juhayni and Mustafa, as cited by Masduqi, ${ }^{26}$ are convinced that the doctrines of Islam are supportive towards the idea of appreciating those whose religious affiliations differ with Muslims. Nevertheless, these two scholars notice that there is a discrepancy between Islam and the practice of Muslims, between Islam and the interpretation of Muslims. Both scholars observe some interpretations and practices of Muslim which discriminate the others.

One Twitter user appreciates Sinta's ideas pertaining to religious harmony, and specifically quotes Sinta's saying, "Co-existence between religious communities also occurred during the era of Majapahit. All these communities were acknowledged by the state. The state served all” (@usmanHAM ID, November 19,2012). This Twitter also quotes Sinta's saying, "The Muslims of Kudus, Central Java, are hesitant to

${ }^{25}$ M.A. Muqtedar Khan, "The Primacy of Political Philosophy," Joshua Cohen and Deborah Chasman (eds), Islam and the Challenge of Democracy: A Boston Review Book (Princeton and Oxford: Princeton University Press, 2004), p. 66.

${ }^{26}$ I. Masduqi, Berislam secara Toleran: Teologi Kerukunan Umat Beragama (Bandung: Mizan, 2011), pp. 190-191. 
slaughter a cow due to their respect and tolerance to their fellow Hindus”. (@usmanHAM ID, November 19, 2012).

All this implies a suggestion that the present-day Indonesian state should acknowledge all faith communities and let the communities to live in harmony.

\section{Sinta Nuriyah Wahid and the Discouragement of Violence Against Minorities}

In the case of contemporary Islam, the Salafiyya is often considered as a movement which plays a role in religious motivated violence. Nevertheless attributing the Salafiyya to the cases of violence in the name of religion is risky since there are varied streams within this movement, and some of these streams dissociate themselves with physical violence.

Din Wahid ${ }^{27}$ classifies the Salafiyya in Indonesia into three clusters: "purist", "haraki", and "jihadi". The purists focus their activities on da'wa (dissemination of Islamic faith) and education and keep away from politics. They stress unconditional loyalty to the government. The harakis reject unconditional loyalty to the government, and conversely, they force the government to implement the provision of Islamic law and they will criticize the government if the government fails to establish Islamic rulings in the state. The jihadists do not only verbally criticize the government but also legitimize the use of violence in their actions. Din Wahid's classification allows us to conclude that violence is more appropriate to be linked with the jihadist stream within the Salafiyya rather than the Salafiyya in general.

Violence if often associated with the groups with apply the literal understanding of the Koran (as observed in the case of the "Jihadist" Salafiyya), but this does not necessarily mean that the groups who apply the rational understanding of the Koran are away from violence. If looking at Islamic history, it is realized that there were also cases of violence which were committed by the Mu'tazila, the rational Islamic sect, under the support of the Caliph al-Ma'mun (reigned 813 - 833). The Caliph al-Ma'mun punished many Muslim scholars who did not agree with the main doctrines of Mu'tazila. At this regard, it may be

27 Din Wahid, "Anatomi Gerakan Salafi di Indonesia," paper presented at the Interdisciplinary Colloquium at the State Institute of Islamic Studies (STAIN) Salatiga, May 28 (2014), pp. 13-14. 
said that it is neither literalism nor rationalism which triggers violence, but rather the politicization of religion.

Sinta is of the opinion that inter-religious and inner-religious conflict does not have any cultural roots in the archipelago. This conflict has been triggered by the strengthening of the puritan and radical movement that eliminates traditional roots and cultural heritage. ${ }^{28}$ Sinta criticizes the cases of abductions carried out by the "Islamic State of Indonesia" (the political movement established by Kartosoewirjo ${ }^{29}$ in 1949 in Tasimalaya, West Java) and the emergence of terrorist bombings in the name of religion. Sinta argues that in fact, the Prophet Muhammad never told his followers to establish an Islamic state. She goes to underline the importance of struggling for inter-religious harmony to advance peace in Indonesia..$^{30}$

In this regard it can be discerned how Sinta built her theological arguments pertaining to the avoidance of terrors in the name of religion. Most specifically, she criticized the idea of formalizing Islamic law in the form of Islamic state, as this was not laid down by the Prophet Muhammad. It seems that she would rather aspire for a pluralist state rather than a theocratic state.

It is of interest to investigate whether Sinta's roles in eliminating radicalism and intolerance within the Muslim community are in conformity to the established patterns within the Nahdlatul Ulama. At this juncture, Emirbayer's and Mische's ${ }^{31}$ three constitutive features of agency will be alluded: iterational, projective and practical-evaluative. The iterational feature of Sinta's agency is discernible in the condition in which Sinta re-actuates parts of the Nahdlatul Ulama's patterns of ideas pertaining to moderate religiosity, most particularly as manifested in the principle of "moderation and balance" (tawassut wa al-I'tidāt). In addition, Sinta seems to continue and develop her husband's legacy

28 "Sinta Nuriyah: Puritanisme Memicu Konflik Agama," http://www.lintas.me/news/nasional/kabar3.com/sinta-nuriyah-puritanisme-memicu-konflik-agama, accessed May 4, 2014.

${ }^{29}$ For the biography of Kartosoewirjo, please see Nugroho Dewanto et al., Kartosoewirjo: Mimpi Negara Islam (Jakarta: Gramedia, 2011).

30 "Sinta Nuriyah ajak Warga Jaga Keutuhan Bangsa," http://antarajatim.com/lihat/berita/69698/sinta-nuriyah-ajak-warga-jaga-keutuhan-bangsa, accessed February 7, 2014.

31 Mustafa Emirbayer and Ann Mische, "What is Agency," AJS, 103 (1998): pp. $962-$ 1023. 
pertaining to the promotion of democracy and human rights, most particularly by acting as a patron for the activists of democracy and human rights.

The practical-evaluative side of Sinta's agency is noticeable from the condition in which Sinta makes practical and normative judgements among alternative feasible trajectories of action, including the increasing plurality within the Nahdlatul Ulama leadership; the attachment of the members of the Nahdlatul Ulama with some political parties with their respective ideologies; as well as the incoming of transnational Muslim actors which modify the religious field in present-day Indonesia.

The projective aspect of Sinta's agency can be observed in the condition in which Sinta reconfigures doable future trajectories of action in accordance with her hopes, fears, and desires for the future. Sinta is attentive to the increasing radicalism within the Muslim community as well as the escalating aspiration and activism to challenge the multiculturalism of the country, in particular, and to endanger the world peace, in general. Sinta's concerns with the sustainability of the plural Indonesia have driven her to undertake some necessary actions to promote moderate religiosity through various media including her writings, her activism, her position at the Puan Amal Hayati Foundation, and her networking with some nongovernmental organisations.

\section{Sinta Nuriyah Wahid, Religious Minority and the Ahmadiyya}

Sinta is recorded as one the personages who actively defend the rights of minority religious groups. This can perceived for instance in her support to the adherents of Ahmadiyya as they were threatened and discriminated by other groups. This leaves an imprint on the minds of Ahmadiyya adherents. Naming the babies of Ahmadiyya with "Sinta Nuriyah" can be deemed to be an indication of their appreciation to Sinta's activism. One Twitter user encountered that one baby of Ahmadiyya in Lombok was named as Transita Sinta Nuriyah (@AlisaWahid November 1, 2012).

Sinta's defence to the rights of the adherents of Ahmadiyya is apparent when she visited and supported the adherents of Ahmadiyya who were forced to live in the mosque for more than one month due to the sealing of mosque by the government of district Bekasi, West Java. The mosque named Al-Misbah is located in Jatibening, Pondok 
Gede, Bekasi. It was 21 adherents of the Ahmadiyya who were forced to live in this mosque. An iron plank declaring the banning of Ahmadiyya activities was lifted in front of the mosque. All the doors were locked and all the fences were covered with zinc plays more than two meters. These Ahmadis, who belong to the "Indonesian Ahmadiyya Congregation", argued that they do not break the rule. They claimed that they do not perform acts of proselytization, rather than only do prayers and other religious rituals.

In response to that, Sinta said, "This sealing is a part of violation of human rights. I hope that the government should take a firm stand. The Indonesian constitution allows us to perform worship and accordingly sealing the house of worship is a violation of religious freedom". At this point, we observe that Sinta grounds her arguments on Indonesian constitution, and employ this as a basis of defending the rights of worship of the minorities.

Sinta notices that the Bakorpakem (Coordinating Agency of the Surveillance of the Mystical Sects of the Society) on April 16, 2008 declared that the Ahmadiyya deviates from Islamic teachings. From 2001 until the end of 2013, she remarks at least 38 local regulations relating to the prohibition of the dissemination of the teachings of Ahmadiyah in West Java and West Nusa Tenggara. Sinta also criticizes the government's policy in dealing with refugees associated with religious motivated conflicts. She paid particular attention to the refugees from the Ahmadiyya and Shi'ism, 32 which do not obtain a sufficient protection from the government.

We also detect Sinta's appreciation with "unrecognized religions". This can be observed from her Ramadan-programmes in which she invites the adherents of "unrecognized religions". Her Ramadanprogramme which was held on July 26, 2012 is worth remarking since this programme was held in Cigugur, Kuningan, West Java, in which many adherents of "Sunda Wiwitan" live. 33 "Sunda Wiwitan" (literally early Sunda) is one of the "unrecognized religions" which is embraced

\footnotetext{
32 "Sinta Nuriyah Wahid Bela Keyakinan Syiah dan Ahmadiyah," http://www.satuislam.org/nasional/sinta-nuriyah-wahid-bela-keyakinan-syiah-dan-ahmadiyah/, accessed February 27, 2015.

33 One of mass-media reports pertaining to this: "Sahur Keliling Sinta dengan Komunitas Adat Sunda," http://www.beritasatu.com/sahur-buka/61835-sahur-keliling-sinta-nuriyah-dengan-komunitas-adat-sunda.html, accessed April 23, 2014.
} 
by some people in West Java. This religion is mostly based on veneration of natural forces and spirits.

The adherents of "Sunda Wiwitan" are appreciative towards Abdurrahman Wahid, due to his pluralist spirit. Abdurrahman's pluralist spirit is observable for instance in his allowance in 1999 to the ritual "Seren Taun" (which has been held most notably by the adherents of "Sunda Wiwitan"). This ritual has been prohibited by the government for seventeen years. ${ }^{34}$ The ritual "Seren Taun" represents a thanksgiving festival which is held by the society after rice harvest. This ritual is originally a kind of thanksgiving and worship to the goddess of rice.

Sinta's concern with minorities is also apparent in her Ramadanprogrammes entitled "buka bersama" (breaking fast together) and "sahur bersama" (early morning-meal together). During this programmes, she often engross many marginalised groups which embrace minority religious sects, transgender people, women and uprooted ethnic groups. It is worth mentioning that these programmes have set in motion since her husband's presidential office (1999-2001) and persisted up to the present time. ${ }^{35}$

During the Ramadan-programme which was held on July 27, 2012 at the City Hall of Purbalingga, Central Java, Sinta emphasized that state has been unable to protect the minorities. To support this standpoint, she pointed to the phenomena of demonstrations against minorities which occur everywhere in the country, as well as burning and sealing of houses of worship. Sinta was concerned with the cases of violence towards minorities by saying, "Those minorities who are also our brothers that should be protected; but what happened is the opposite. The state has experienced a crisis". In addition, she criticized the mentality of some religious groups, "Many groups consider themselves the closest to God and the holiest; and see those not in line with them as devils. This is really alarming". ${ }^{36}$

34 Sahur Keliling Sinta dengan Komunitas Adat Sunda," http://www.beritasatu.$\mathrm{com} /$ sahur-buka/61835-sahur-keliling-sinta-nuriyah-dengan-komunitas-adat-sunda.html, accessed on April 23, 2014.

35 "Sinta Nuriyah Wahid Buka Puasa Bersama Komunitas Konghucu Jambi," http://www.beritasatu.com/nusantara/125732-sinta-nuriyah-wahid-buka-puasa-bersama-komunitas-konghucu-jambi.html, accessed on August 22, 2013.

36 "Galau, Sinta Gus Dur Sahur Bareng Sumanto Kanibal,“ http://en.tempo.co/read/news/2012/07/28/151419852/Galau-Sinta-Gus-Dur-Sahur-Bareng-Sumanto-Kanibal 
Sinta's standing as religious scholar and the Chairman of the Special Rapporteur on Freedom of Religion of the National Commission for Women allow her to pay a strong attention to the cases of discrimination towards women from minority groups. Sinta says, "They often suffer sexual harassment. The discrimination suffered by the women from minority groups does not cease at this point. These women do not receive equal government services. They discriminated in the health services, including reproductive health such as during the childbirth." 37 Sinta went on to allude to other forms of discrimination underwent by women from minority groups, by saying, "The women from minority groups are secluded from the rest of community. They are threatened to undergo polygamous marriage or forced to be divorced from their respective husbands" 38 .

Because of her defenses to the woman's rights and minorities in Indonesia, Sinta was granted "Lifetime Achievement Award" granted by Rakyat Merdeka newspaper. This award signified an appreciation to her contribution to the development of the country. Sinta was bestowed "Lifetime Achievement Award" most specifically due to her struggle in defending the rights of women and minorities in Indonesia. It is through Puan Amal Hayati Foundation, that Sinta is very active advocate for gender equality and minority rights.

Sinta pointed out that she would continue her struggle to provide advocacy for women and the oppressed minorities. She went to stress that everybody is to get independence as individual. She dedicated the award for her colleagues in Puan Amal Hayati Foundation. Sinta considered the struggle for women's empowerment as a collective endeavor, rather than a single individual effort. Accordingly she regards her award as a kind of appreciation to her fellow Women's activists. ${ }^{39}$

37 "Sinta Wahid: Perempuan Minoritas Rawan Pelecehan," (December 23, 2014), http://www.tempo.co/read/news/2014/12/23/078630415/Sinta-Wahid-PerempuanMinoritas-Rawan-Pelecehan, accessed February 21, 2015.

38 "Ini Akibat Intoleransi Agama bagi Perempuan," (December 22, 2014), http://www.tempo.co/read/news/2014/12/22/078630359/Ini-Akibat-Intoleransi-Agama-bagi-Perempuan, accessed February 20, 2015.

39 "Sejumlah Tokoh Nasional Terima Anugerah Rakyat Merdeka," http://infopublik.org/read/43476/sejumlah-tokoh-nasional-terima-anugerah-rakyat-merdeka2013.html, accessed February 6, 2014. 
Sinta seems to aspire and continue her husband's activism in defending minorities. The charisma of her husband also allows her to build the networks in maximizing her influence and outreach of her activism. Masduqi ${ }^{40}$ rightly points out that Abdurrahman Wahid (Sinta's husband) is known as inclusive and tolerant scholar who has done devoted himself in defending the rights of minorities. Abdurrahman is reported to have saying, "As long as I live, I will defend the (rights of) Ahmadiyya. If somebody says that the Ahmadiyya is deviant, it is up to him. But the Indonesian Constitution of 1954 grants them the freedom in expressing their opinion". It is worth remarking that Abdurrahman did not defend the theological aspects of the Ahmadiyya but rather defend their rights as citizens which have to be protected by the state.

Abdurrahman is also known as the president who included once again the Confucianism as one of the officially recognized religions in Indonesia. This can be observed from his issuance of the Presidential Decree Number 6/2000, and accordingly the civil rights of the adherents of Confucianism have been restored, such as the rights to obtain subject on Confucianism in public school. ${ }^{41}$

Although Sinta is quite progressive in promoting gender equality, minority rights and religious freedom, it seems that she does not stick to liberalism in the sense of pushing back the religion to the private sphere. Madung ${ }^{42}$ reveals two theorizing models of political philosophy pertaining to the discourse on the relationship between state and religion, namely liberalism and perfectionism. Liberalism aspires for the separation between state and religion, and accordingly religion is considered as private domain. Perfectionism is convinced that the regulation of good life falls within the central concern of politics. In perfectionism, the thematization of the notion of good life such as religion and ideology should be allocated in public space. Madung goes on to stress that in Indonesia the role of thematization of good life has been played by Pancasila, the country's state ideology. Pancasila is concerned with the translation of religious values into public morality.

\footnotetext{
${ }^{40}$ Masduqi, Berislam secara Toleran, pp. 133-134.

${ }^{41}$ Rumadi, Renungan Santri, pp. 266-267.

42 Otto Gusti Madung, Negara, Agama dan Hak-bak Asasi Manusia (Maumere: Penerbit Ledalero, 2014), pp. 22-23.
} 
Sinta realizes that the promotion of minority rights in the circle of Indonesian Muslims necessitates the existence of figures of authority, which are able to justify the virtues of minority rights within the corpus of Islamic doctrine. Sinta belongs to the category of figures which perform this endeavor.

\section{Conclusion}

Sinta is female Muslim scholar-activist whose main domains of activism include da'wa activism, women's rights activism, and minority rights activism. Her current activism is mostly concentrated on women's rights activism, and minority rights activism. It is preferred not to perceive this as the "shifting of activism" but rather as "adding behaviors and tasks to Sinta's specific role" or "incorporating diverse actions into Sinta's new distinct role". In this regard, it is stick to Turner's ${ }^{43}$ conception on role differentiation.

Sinta has done her best to promote minority rights. Her activism can be felt most notably in the defending religious minorities in general, and the Ahmadiyya, in particular. Sinta pays more particular attention the women of minority groups, which suffer more discrimination since they assign "double minority".

Sinta's authority rests in her erudition of Islamic knowledge, which she gains mostly during her study at the Pesantren. Her writings and talks obviously indicate that she posit herself as Muslim scholar and women's activist. Her charisma derived mainly from her father, Muh Syakur and her husband, Abdurrahman Wahid. Her position as the wife of Abdurrahman Wahid plays a significant role in her standing as authority on Islam in Indonesia. Another source of Sinta's charisma is her spiritual training (riyäda rübäniyya). As a pious Muslim and a person who has been nurtured within the milieu of religious scholars, she has been acclimatized to undergo such training.

Sinta's credentials of authority allow her to speak in the name of Islam. Her grounding in traditionalist Muslim scholarship also allows her to criticize some features of Islamic scholarship, most particular hadith and the opinions of Muslim scholars which disregard the position of women, without losing her authority.

\footnotetext{
${ }^{43}$ Ralph H. Turner, "Role Theory," Jonathan H. Turner (ed.), Handbook of Sociological Theory (New York: University of California, 2006), p. 236.
} 
Sinta uses her influence to recommend the government to take necessary actions in protecting minorities. She asked the government to work together to overcome various intolerance faced by minorities, especially women. She "exploits" her credibility and standing to influence the policy makers at national level and this is not without reasoning. Sinta seems to aspire and continue her husband's activism in defending minorities, most particularly the Ahmadiyya. The charisma of her husband also allows her to build the networks in maximizing her influence and outreach of her activism. [] 


\section{References}

\section{Books and Articles}

Azra, Azyumardi. "Pengantar." Iskandar Zulkarnain (ed.). Gerakan Ahmadiyah di Indonesia. Yogyakarta: LKiS, 2005.

Baso, Ahmad. "Pengantar Editor." Siti Musdah Mulia. Muslimah Reformis: Perempuan Pembaru Keagamaan. Bandung: Mizan, 2004.

Bendix, Reinhard. "Reflections on Charismatic Leadership." Asian Survey, 7 (1967): pp. 341-352.

Crouch, Melissa. Indonesia, Militant Islam and Abmadiyah: Origins and Implications, SSRN Scholarly Paper. New York: Social Science Research Network, 2010.

Dewanto, Nugroho et al.. Kartosoewirjo: Mimpi Negara Islam. Jakarta: Gramedia, 2011.

Effendy, Bakhtiar. "Islam: Eksistensi Agama dalam Politik Indonesia." S.P. Lili Tjahjadi. Agama dan Demokratisasi: Kasus Indonesia. Yogyakarta: Kanisius, 2011, 77-97.

Emirbayer, Mustafa and Ann Mische. "What is Agency." AJS, 103 (1998): pp. 962-1023.

Khan, M.A. Muqtedar. "The Primacy of Political Philosophy." Joshua Cohen and Deborah Chasman (eds). Islam and the Challenge of Democracy: A Boston Review Book. Princeton and Oxford: Princeton University Press, 2004.

Madung, Otto Gusti. Negara, Agama dan Hak-hak Asasi Manusia. Maumere: Penerbit Ledalero, 2014.

Marwal, Ilyas. "Kata Pengantar Ahli." Ihsan Ilahi Dzahir. Abmadiah Qadianiyah: Sebuah Kajian Analitis, translated by Harapandi Dahri. Jakarta: Balai Penelitian dan Pengembangan Agama, 2008.

Masdar, Umaruddin. Membaca Pikiran Gus Dur dan Amin Rais tentang Demokrasi. Yogyakarta: Pustaka Pelajar, 1999.

Masduqi, I. Berislam secara Toleran: Teologi Kerukunan Umat Beragama. Bandung: Mizan, 2011.

Mulia, Siti Musdah. Muslimah Reformis: Perempuan Pembaru Keagamaan. Bandung: Mizan, 2004. 
Nuriyah, Sinta. "Pengantar." Forum Kajian Kitab Kuning, Kembang Setaman Perkawinan: Analisis Kritis Kitab Uqud al-Lujayn. Jakarta: Kompas, 2005.

Rumadi. Renungan Santri: Dari Jihad hingga Kritik Wacana Agama. Jakarta: Erlangga, 2002.

Savitri, Tina. "Sinta Nuriyah Wahid dan Jurus Menembus Pesantren." Pesona (2011): pp. 62-66.

Turner, Ralph H. "Role Theory." Jonathan H. Turner. Handbook of Sociological Theory. New York: University of California, 2006.

Wahid, Din. "Anatomi Gerakan Salafi di Indonesia." paper presented at the Interdisciplinary Colloquium at the State Institute of Islamic Studies (STAIN) Salatiga, May 28, 2014.

Xueqin, Shi. "Implications of Islam and Pluralism in Post-Suharto Indonesia." Suvannabhumi, 6 (2014): pp. 19-36.

Zulkarnain, Iskandar. Gerakan Abmadiyah di Indonesia. Yogyakarta: LKiS, 2005.

\section{Internet Sources}

"Dukungan Sinta Nuriyah Wahid terhadap Derita." (May 6, 2013), http:// news.metrotvnews.com/read/2013/05/06/151403/duk ungan-sinta-nuriyah-wahid-terhadap-derita, accessed April 26, 2014.

"Galau, Sinta Gus Dur Sahur Bareng Sumanto Kanibal." July 28, 2012), http://en.tempo.co/read/news/2012/07/28/151419852/Galau-Sinta-Gus-Dur-Sahur-Bareng-Sumanto-Kanibal

"Ini Akibat Intoleransi Agama bagi Perempuan." (December 22, 2014), http://www.tempo.co/read/news/2014/12/22/078630359/Ini-Akibat-Intoleransi-Agama-bagi-Perempuan, accessed February 20, 2015.

"PM Says Human Rightism, Humanism, Secularism New Religion Threatening Islam." http://www.themalaymailonline.com/malaysia/article/pm-says-human-rightism-humanism-secularismnew-religion-threatening-islam, accessed on May 16, 2014.

"Sejumlah Tokoh Nasional Terima Anugerah Rakyat Merdeka", http://infopublik.org/read/43476/sejumlah-tokoh-nasional-te- 
rima-anugerah-rakyat-merdeka-2013.html, accessed February 6, 2014.

"Sinta Nuriyah ajak Warga Jaga Keutuhan Bangsa." http://antarajatim.com/lihat/berita/69698/sinta-nuriyah-ajak-warga-jagakeutuhan-bangsa, accessed February 7, 2014.

"Sinta Nuriyah Hadiri Semalam bersama Gus Dur." http://www.wahidinstitute.org/v1/News/Detail/?id=438/hl=id/Sinta_Nuriya h_Hadiri_Semalam_Bersama_Gus_Dur, accessed April 5, 2014.

"Sinta Nuriyah Wahid Bela Keyakinan Syiah dan Ahmadiyah." http://www.satuislam.org/nasional/sinta-nuriyah-wahid-belakeyakinan-syiah-dan-ahmadiyah/, accessed February 27, 2015.

"Sinta Nuriyah Wahid Buka Puasa Bersama Komunitas Konghucu Jambi, http://www.beritasatu.com/nusantara/125732-sinta-nuriyah-wahid-buka-puasa-bersama-komunitas-konghucu-jambi.html, accessed on August 22, 2013.

"Sinta Nuriyah Wahid: tidak ada Pola Umum Kekerasan pada Perempuan.” http://www.satuharapan.com/read-detail/read/sinta-nuriyah-wahid-tidak-ada-pola-umum-kekerasan-pada-perempuan, accessed May 15, 2014.

"Sinta Nuriyah: Puritanisme Memicu Konflik Agama." http://www.lintas.me/news/nasional/kabar3.com/sinta-nuriyah-puritanisme-memicu-konflik-agama, accessed May 4, 2014.

"Sinta Wahid: Kalau Bilang Toleransi Lebih Baik Mbok Lihat Kondisi Sebenarnya" (August 16, 2013). http://nasional.kompas.com/$\mathrm{read} / 2013 / 08 / 16 / 1811371 /$ Sinta.Wahid.Kalau.Bilang.Toleransi .Lebih.Baik.Mbok.Yo.Lihat.Kondisi.Sebenarnya, accessed December 19, 2013.

"Sinta Wahid: Perempuan Minoritas Rawan Pelecehan" (December 23, 2014). http://www.tempo.co/read/news/2014/12/23/078630415/Sinta-Wahid-Perempuan-Minoritas-Rawan-Pelecehan, acessed February 21, 2015.

"Yenny Wahid dan Puasa Daud Sinta Nuriyah", (December 23, 2014). http://www.tempo.co/read/news/2014/12/23/219630423/Ye nny-Wahid-dan-Puasa-Daud-Sinta-Nuriyah, accessed February 9, 2015. 
Asfa Widiyanto

"Sahur Keliling Sinta dengan Komunitas Adat Sunda." http://www.beritasatu.com/sahur-buka/61835-sahur-keliling-sinta-nuriyahdengan-komunitas-adat-sunda.html, accessed April 23,2014.

"Sambutan Istri Alm Gus Dur (Sinta Nuriyah Wahid) pada acara peringatan 1000 hari Gus Dur." https://www.youtube.com/watch?v=dcNZnVA_5KE, accessed June 5, 2014.

\section{Interviews}

Interview with Husein Muhammad, March 25, 2015.

Interview with Sinta Nuriyah Wahid, Jakarta, September 7, 2011. 